\title{
ASSESSMENT OF BONE DENSITY IN PATIENTS WITH SCOLIOSIS NEUROMUSCULAR SECONDARY TO CEREBRAL PALSY
}

\author{
AVALIAÇÃO DA DENSIDADE ÓSSEA EM PACIENTES COM ESCOLIOSE NEUROMUSCULAR \\ SECUNDÁRIA À PARALISIA CEREBRAL
}

\section{EVALUACIÓN DE LA DENSIDAD ÓSEA EN PACIENTES CON ESCOLIOSIS NEUROMUSCULAR SECUNDARIA PARA PARÁLISIS CEREBRAL}

Charbel Jacob Júnior ${ }^{1}$, Igor Machado Barbosa ${ }^{1}$, José lucas Batista Júnior ${ }^{1}$, Rayana Bomfim Leonel², Larissa Grobério Lopes Perim², Tarcísio Guimaräes Silva Olivelra²

\begin{abstract}
Objective: To evaluate bone mineral density in patients with neuromuscular scoliosis secondary to spastic quadriplegic cerebral palsy Methods: A prospective descriptive study in which, in addition to bone densitometry, the anthropometric data of the patients were assessed As inclusion criterion we adopted patients with spastic quadriplegic cerebral palsy, wheelchair users, aged between 10 and 20 years and with neuromuscular scoliosis. Results: We evaluated 31 patients, 20 female, whose average age was 14.2 years. The mean bone density was -3.2 standard deviation (Z-score), with mean biceps circumference of $19.4 \mathrm{~cm}$, calf circumference $18.6 \mathrm{~cm}$ and BMl of $13.6 \mathrm{~kg} / \mathrm{m}^{2}$. Conclusion: There is a high incidence of osteoporosis in patients with neuromuscular scoliosis secondary to spastic quadriplegic cerebral palsy
\end{abstract}

Keywords: Scoliosis; Neuromuscular diseases; Osteoporosis.

\section{RESUMO}

Objetivo: Avaliar a densidade mineral óssea em pacientes portadores de escoliose neuromuscular secundária a paralisia cerebral tetraespástica. Métodos: Estudo prospectivo, descritivo em que se avaliou além da densitometria óssea dados antropométricos dos pacientes. Como critério de inclusão adotamos pacientes com paralisia cerebral tetraespástica, cadeirantes com idade entre 10 e 20 anos e com escoliose neuromuscular. Resultados: Avaliamos 31 pacientes, 20 do sexo feminino cuja média de idade foi de 14,2 anos. A média da densitometria óssea foi -3,2 desvio padrão (Z-score), sendo a média da circunferência bicipital 19,4 cm, da panturrilha 18,6 cm e do IMC de 13,6 Kg/m². Conclusão: Existe elevada incidência de osteoporose em pacientes portadores de escoliose neuromuscular secundário a paralisia cerebral tetraespástica.

Descritores: Escoliose; Doenças neuromusculares; Osteoporose.

\section{RESUMEN}

Objetivo: Evaluar la densidad mineral ósea en pacientes portadores de escoliosis neuromuscular secundaria para parálisis cerebral tetraespástica. Métodos: Estudio prospectivo y descriptivo, en el cual se evaluaron, además de la densitometría ósea, los datos antropométricos de los pacientes. Como criterio de inclusión adoptamos pacientes con parálisis cerebral tetraespástica, usuarios de silla de ruedas, con edad entre 10 y 20 años y con escoliosis neuromuscular. Resultados: Evaluamos a 31 pacientes, 20 del sexo femenino, cuyo promedio de edad fue de 14,2 años. El promedio de la densitometría ósea fue -3,2 desvío estándar (Z-score), siendo el promedio de la circunferencia bicipital $19,4 \mathrm{~cm}$, de la pantorrilla 18,6 cm y del IMC, 13,6 kg/m². Conclusión: Existe elevada incidencia de osteoporosis en pacientes portadores de escoliosis neuromuscular secundaria para parálisis cerebral tetraespástica.

Descriptores: Escoliosis; Enfermedades neuromusculares; Osteoporosis.

\section{INTRODUCTION}

There are many neuromuscular diseases that develop deformities of the spine. The most frequent is cerebral palsy, which has an incidence ranging from 25 to 100\% of patients, depending on the degree of neuromuscular involvement. ${ }^{1}$ Its etiology is secondary to an imbalance of muscle strength in the axial skeleton ${ }^{2}$ due to a lesion in the upper and lower motor neurons. ${ }^{3}$ Normally, the scoliosis curve presents a " $\mathrm{C}$ " shape associated with pelvic obliquity, and many times its progression is frequent, even after skeletal maturity. ${ }^{4}$

Thus, in cases of severe deformities, or where progression of the curve is detected, surgical treatment is necessary to prevent progression, restore or maintain the sagittal and coronal balance, and the ability to sit, leading to a significant improvement in the quality of life of these patients after surgical treatment.

In these cases, despite the need for surgical treatment, the rate of complications is very high, and is directly related to the impairment of cardiopulmonary and gastrointestinal functions and the degree of patient nutrition. ${ }^{5}$ Of all the possible complications, infection and loosening of the synthesis material used to correct the deformity are the most common. ${ }^{6}$

Failure of the pedicular screws to fix into the spine can occur due to osteoporosis of the vertebral body, which in these patients, is caused by factors such as the severity of the neurological impairment, increasing difficulty in feeding, and the use of anticonvulsants. ${ }^{7}$

There have been few studies that analyze the bone mass in

1. Hospital Santa Casa de Misericórdia de Vitória, Vitória, ES, Brazil.

2. Escola Superior de Ciências da Saúde da Santa Casa de Misericórdia de Vitória, Vitória, ES, Brazil.

Study conducted at the Orthopedic Outpatient Clinic of the Hospital Santa Casa de Misericórdia de Vitória, Vitória, ES, Brazil.

Correspondence: jcharbel@gmail.com, grupodecoluna@santacasavitoria.org 
patients with spastic quadriplegic cerebral palsy, and there are many complications arising from loosening of the synthesis material in this type of patient. This complication can be prevented through proper analysis and early treatment of patients with low bone mass. The aim of this study was to analyze the bone mass of these patients, in order to be able to adopt appropriate preventive measures.

\section{CASE STUDY AND METHOD}

This is a prospective, descriptive study, approved by the Ethics Committee of the Hospital da Santa Casa de Misericórdia de Vitória, ES, Brazil. Based on a data survey carried out in the period from February 2012 to January 2013, the inclusion criteria adopted were patients with neuromuscular scoliosis due to cerebral palsy with spastic quadriplegic component, and wheelchair users with neuromuscular scoliosis. Patients aged under 9 years or over 20 years were excluded, as were patients whose scoliosis was not of neuromuscular origin due to cerebral palsy.

The sample was by convenience, according to the attendance of these patients at the Orthopedics Outpatient Clinic of the HSCMV. A total of 31 patients were assessed: 20 females and 11 males, with a mean age of 14.2 years.

The bone mass of each patient was then verified, based on bone densitometry of the lumbar spine encoded in a Lunar Prodigy Advance device, model PA+41606, which produces bone densitometries scanned through $\mathrm{X}$-ray in constant potential source at $76 \mathrm{kV}$ and dose-efficient K-edge filter. These were computer-aided using the software Prodigy bis, based on Windows ${ }^{\circledR}$

The results were numerically represented by absolute values and percentages, and documented in protocols. The analysis of the data was performed using the software Microsoft Office/Excel $2007^{\circledR}$ and GraphPad Prism ${ }^{\circledR}$ (San Diego, CA, USA).

In addition to bone mass, the following anthropometric measurements were evaluated in these patients: height, weight, BMI, biceps circumference and calf circumference. It was determined whether they had gastrostomy, were undergoing physiotherapy, or used adapted wheelchairs. Laboratory tests were also performed: complete blood count, TSH, free T4, potassium, serum calcium and serum iron, ferritin, transferrin, PCR, total protein and albumin.

\section{RESULTS}

Of the 31 patients analyzed, 11 were undergoing continual motor physiotherapy, 11 used adapted wheelchairs, and six had gastrostomy for adjuvant nutritional treatment.

The anthropometric measurements had average weight of 28.0 $\mathrm{kg}$, height equal to $143.6 \mathrm{~cm}$, biceps circumference of $19.4 \mathrm{~cm}$, calf circumference of $18.6 \mathrm{~cm}$ and body mass index (BMI) of 13.6.

The mean values of the laboratory tests were within normal limits. (Table 1)

Table 1. Average of the laboratory tests.

\begin{tabular}{c|c|c}
\hline & Average value & Reference value \\
\hline Hemoglobin & 13.52 & $12-14 \mathrm{~g} / \mathrm{dL}$ \\
\hline Hematocrit & 39.94 & $38-42 \%$ \\
\hline Total protein & 7.21 & $6.0-8.0 \mathrm{~g} / \mathrm{dL}$ \\
\hline Albumin & 4.42 & $3.5-5.5 \mathrm{~g} / \mathrm{dL}$ \\
\hline TSH & 2.38 & $0.350-5.50 \mathrm{uUl} / \mathrm{mL}$ \\
\hline FT4 & 1.16 & $0.70-2.0 \mathrm{ng} / \mathrm{dL}$ \\
\hline Serum calcium & 8.89 & $8.4-10.6 \mathrm{mg} / \mathrm{dL}$ \\
\hline Potassium & 4.26 & $3.5-5.2 \mathrm{mEg} / \mathrm{L}$ \\
\hline Ferritin & 34.01 & $10-140 \mathrm{ng} / \mathrm{mL}$ \\
\hline Serum iron & 92.15 & Men: $60-150 \mathrm{mcg} / \mathrm{dL}$ \\
\hline Transferrin & 218.19 & $200-360 \mathrm{mg} / \mathrm{dL}$ \\
\hline PCR & 5.29 & $<6 \mathrm{mg} / \mathrm{L}$ \\
\hline
\end{tabular}

Analyzing the results of the bone densitometry, we found a mean Z-score in the lumbar spine of -3.3, with a minimum value of -6.0 and a maximum of 2.1. Therefore, of the 31 patients analyzed, $25(80.7 \%)$ had osteoporosis, 5 (16\%) osteopenia and 1 (3.3\%) normal density.

Dividing the analysis of the results, we found six patients with gastrostomy and 25 without gastrostomy, where we observed Z-scores of -3.61 and -3.14 , respectively.

\section{DISCUSSION}

The surgical treatment of neuromuscular scoliosis is often difficult because of the various possible complications and the constant need for a trained multidisciplinary team to perform it. ${ }^{8}$ However when surgical treatment is indicated, we must seek to avoid these complications as far as possible.

Poor nutrition in these patients due to difficulty feeding, the use of anticonvulsants, and neurological impairments can lead to a decrease in bone mass which leads to a higher rate of loosening of the synthesis material, ${ }^{6}$ requiring, in these cases, new surgical interventions to decrease the rate of nonunion.

Although we are aware of the possibility of low bone mass in these patients, there is no preoperative routine for its evaluation, and we have found no studies in the literature that specify the average bone mineral density (BMD) value in these patients.

To assess the BMD and diagnose osteoporosis in children and adolescents, we used the Z-score, which is the number of standard deviations resulting from the comparison between the $B M D$ value of the child, and the average BMD values of a standard population of the same age and sex. The values are considered abnormal when the Z-score is less than -1. In these cases, there are no clearly-defined, validated thresholds for osteopenia and osteoporosis, but it is considered that a child has osteoporosis when the Z-score is less than $-2 .^{7}$

According to a study by Henderson et $\mathrm{a}^{9}{ }^{9}$ that included 139 children and adolescents with cerebral palsy of variable severity, the BMD was assessed in the proximal femur and lumbar spine, where the mean Z-score for the lumbar spine was $-0.92 \pm 0.14$, but in that work, a heterogeneous group of patients was used in which the factor that best correlated with the low BMD was the ability to walk. In our study, we evaluated a homogeneous group in which all patients are non-ambulant, and we used the BMD only of the lumbar spine, where we observed that there was a greater loss of bone mass, with an average Z-score of -3.3.

Children with mental disabilities may present communication difficulties, oromotor and postural dysfunctions, intolerance, and changes of appetite caused by medication, which often interfere qualitatively and quantitatively in the intake of nutrients, reflecting on their nutritional status. ${ }^{10}$ The studies available indicate that the majority of them have anthropometric indicators smaller than children without disabilities, and that adequate intake of macro- and micronutrients, such as calcium and iron, is rare. ${ }^{11}$

In the study by Sullivan et $a /,{ }^{11}$ it is reported that these children have a diet based on drinks made with milk and its derivatives, mainly because their liquid or pasty consistency makes feeding these patients easier. The low variety and quantity of nutrients may contribute to a situation of malnutrition and consequent electrolyte spoliation, compromising the electrolyte balance. Another important factor, cited in the works of Farhat et al ${ }^{12}$ and Goodman et al, ${ }^{13}$ which may be related to malnutrition in these patients, is the chronic treatment with some anticonvulsants, considered hepatic inducers. They act on the enzymatic activity of the P450 system, thereby reducing the availability of vitamin $D$ in the organism and consequently interfering with the absorption of calcium and phosphorus. However, in our study, the loss of potassium, serum calcium, iron and albumin remained average, within the limits of normality.

We found a high number of patients with neuromuscular scoliosis with osteoporosis, and this may influence the final outcome 
of treatment. Therefore, the investigation of the presence or absence of low bone mass in these patients should be instituted as routine, and the earlier the treatment is started, the less postoperative complications there will be.

\section{CONCLUSIONS}

There is high incidence of osteoporosis in patients with neuromuscular scoliosis secondary to spastic quadriplegic cerebral palsy.

\section{ACKNOWLEDGEMENTS}

We thank Dr. Rodrigo Rezende for his teaching and his dedication to our group, and particularly to the patients of this institution.

We offer our deepest sympathy and eternal longing, and pray that God will comfort all our hearts.

All authors declare no potential conflict of interest concerning this article.

\section{REFERENCES}

1. Olafsson $Y$, Saraste $H$, Al-Dabbagh Z. Brace treatment in neuromuscular spine deformity. J Pediatr Orthop. 1999;19(3):376-9.

2. Erickson MA, Baulesh DM. Pathways that distinguish simple from complex scoliosis repair and their outcomes. Curr Opin Pediatr. 2011;23(3):339-45.

3. Weinstein SL. The pediatric spine: principles and practice. 2nd ed. New York: Lippincott Williams \& Wilkins; 2001.

4. Daher MT, Cavali PTM, Santo MAS, Rossato, AJ, Lehoczki MA, Landim E. Correlação entre o número de parafusos e o percentual de correção no tratamento cirúrgico da escoliose neuromuscular. Coluna/Columna. 2009;8(2):105-9.

5. Mulpuri K, Perdios A, Reilly CW. Evidence-based medicine analysis of all pedicle screw constructs in adolescent idiopathic scoliosis. Spine (Phila Pa 1976). 2007;32(Suppl 19):S109-14.

6. Henderson RC, Lark RK, Gurka MJ, Worley G, Fung EB, Conaway M, et al. Bone density and metabolism in children and adolescents with moderate to severe cerebral palsy. Pediatrics. 2002;110(1 Pt 1):e5.

7. Canhão H, Fonseca JE, Queiroz MV. Diagnóstico e terapêutica da osteoporose na idade pediátrica. Acta Med Port. 2004;17:385-90.

8. Master DL, Son-Hing JP, Poe-Kochert C, Armstrong DG, Thompson GH. Risk factors for major complications after surgery for neuromuscular scoliosis. Spine (Phila Pa 1976). 2011;36(7):564-71.

9. Henderson RC, Lin PP, Greene WB. Bone-mineral density in children and adolescents who have spastic cerebral palsy. J Bone Joint Surg Am. 1995;77(11):1671-81.

10. Fung EB, Samson-Fang L, Stallings VA, Conaway M, Liptak G, Henderson RC, et al.Feeding dysfunction is associated with poor growth and health status in children with cerebral palsy. J Am Diet Assoc. 2002;102(3):361-73.

11. Sullivan PB, Juszczak E, Lambert BR, Rose M, Ford-Adams ME, Johnson A. Impact of feeding problems on nutritional intake and growth: Oxford Feeding Study II.Dev Med Child Neurol. 2002;44(7):461-7.

12. Farhat G, Yamout B, Mikati MA, Demirjian S, Sawaya R, El-Hajj Fuleihan G. Effect of antiepileptic drugs on bone density in ambulatory patients. Neurology. 2002;58(9):1348-53.

13. Goodman SB, Jiranek W, Petrow E, Yasko AW. The effects of medications on bone. J Am Acad Orthop Surg. 2007;15(8):450-60. 